\title{
The Analysis of Instagram Use as a Media of Tourism Promotion in Malang City (Case Study on @Amazingmalang Instagram Account)
}

\author{
Alma Saquille Rashad ${ }^{1}$, Tri Mega Asri²* \\ ${ }^{1}$ Department of Biology, Faculty of Mathematics and Natural Sciences, University of Brawijaya, Malang, Indonesia \\ ${ }^{2}$ Laboratorium of Physiology, Faculty of Medicine, University of Brawijaya, Malang, Indonesia
}

Abstract

Today's social media use is very influential in the lives and perspectives of finding a wide variety of information. Most social media users prefer to use Instagram as an attractive information provider app with Visual media treats in the form of images and videos tourism industry that has undergone a lot of rapid progress. Like the city of Malang, it becomes the main tourist destination for tourism by foreign and foreign tourists when they want to go on holiday. This research discussed the success rate of Instagram as a tourism promotion media in Malang. This type of research is qualitative descriptive research. The data collection techniques used are three ways: interviews, questionnaires, and case studies. The results showed the success rate of tourism promotion in Malang City using the Instagram @amazingmalang.

Keywords: Instagram, promotions, tourism.

\section{INTRODUCTION}

Along with the times, the development of communication science can not be separated from information technology. Without communication, information cannot be conveyed. In the current era of globalization, information and communication technology plays an important role in various aspects of human life. The role of information technology and communication will increase along with the times and eventually become a basic element in human life.

Social media, as one of the most powerful online networking tools, has been integrated into social and economic life in the real world. Social media marketing is a powerful way for businesses of all sizes to reach prospects and customers [1]. The customers are already interacting with brands through social media, and if the brands are not speaking directly to their audience through social platforms like Facebook, Twitter, Instagram, and Pinterest. Considering the survey report for the year 2018 [2], the second reason 1 st rank about using the internet, $19.1 \%$ said The Social Media. About internet content (Social Media), the most accessed $17.8 \%$ is Instagram. Of the many information technologies that can be accessed easily from anywhere is to use print or mass media commonly known through television, radio, internet, newspapers, and others. Tourism businesses use a lot of media to promote tourism

\footnotetext{
* Corespondence Address:

Tri Mega Asri

E-mail : trimega@ub.ac.id

Address : Program of Vocational Education, University of Brawijaya, Veteran Malang, 65145.
}

in their area. One of the easiest media to promote tourism is Instagram. The presence of Instagram makes it easy for people around the world to find out the potential of tourism they want to visit.

According to the media intelligence company Isentia, they captured discussions on social media related to tourism and the year-end holiday of 139,438 buzz in the past month. This discussion is counted from 1 October to 8 November 2019 [3].

During this period, Yogyakarta became the area that most talked about by people, which is 40,988 buzz. The second place is in Bali with 37,792 Buzz, followed by East Java with 20,146 buzz. Furthermore, there is central Java with 16,143 Buzz, North Sumatera 6,558 Buzz, South East Sulawesi 4,661 Buzz, South Sulawesi 3,996 Buzz, and West Papua 9,149 Buzz social media talks. From this, we can conclude that East Java tourism ranks $3^{\text {rd }}$ with the most buzzer, including @amazingmalang, who participated in tourism promotion in Malang City [3].

Instagram account @amazingmalang provides many recommendations for information about tourism in the city of Malang. The account created on 20th October 2015, has gained 470,000 followers with a total of 5,523 accounts followed. Until now, the number of posts on the @amazingmalang account is 5,745 images with 20 videos on IG TV, a number that is extraordinary for the development over the past four years. Not only that, but @amazingmalang account has also grown to have a youtube channel and an @amazingmalangeats account that offers shop or restaurant recommendations in Malang. Achievements continue to be achieved by the @amazingmalang account, until 
now it has its own TV show and cooperates with Malang Struddle.

@Amazingmalang account has the following highlights: Travel hack, kid-friendly, recommendations, cheap travel, culinary, behind the scenes, wallpapers, photo spots, beaches, and local events. @Amazingmalang account activity is a post about the recommendations of natural tourism in Malang city, besides this account also repost for photos on the Instagram account of other people who go to the tourism place in Malang city. The goal is to give a good effect to the content on the @amazingmalang account and also make the photo owner popular.

In this case, it can be certain that the account @amazingmalang not only have one admin. The way they develop this account is to often do the 25,000 meal voucher on the condition that the person is taking a survey created by them and tagging the other five target audience. The result is that more and more people are aware of this account and make this account a reference to finding a tourist spot. In this paper, we will discuss the analysis of the success rate of Instagram as tourism promotion media in Malang, a case study on Instagram account @amazingmalang seen from the number of public interest with the existence of this account.

\section{MATERIAL AND METHOD}

The population in this research is active account owner on Instagram and follow an Instagram account @amazingmalang Malang that actively visits the account timeline @amazingmalang at least 1 time a week. According to Sugiyono [4], a decent sample size in the study was 30 to 500 . So in this study took 120 samples. The sampling method uses purposive sampling.

\section{Data Collection}

In this study used data collection techniques by giving questionnaires to respondents who became samples. The question presented in this questionnaire is a closed question, that is, the model of the question has been provided the answer, so that the respondent only choose from an alternative answer that corresponds to his or her opinion or choice. From the answers to the list of questions asked to respondents, we use a scale rating, which is a scale containing five levels of answer preference. All data in the entry to the computer by using the program Microsoft Excell 2010. Further tabulation of variable data to view and analyze the promotion level of Attention, Interest, Desire, Action (AIDA) [5] showed in Table 1.

Table 1. Variable Operational Definitions of AIDA

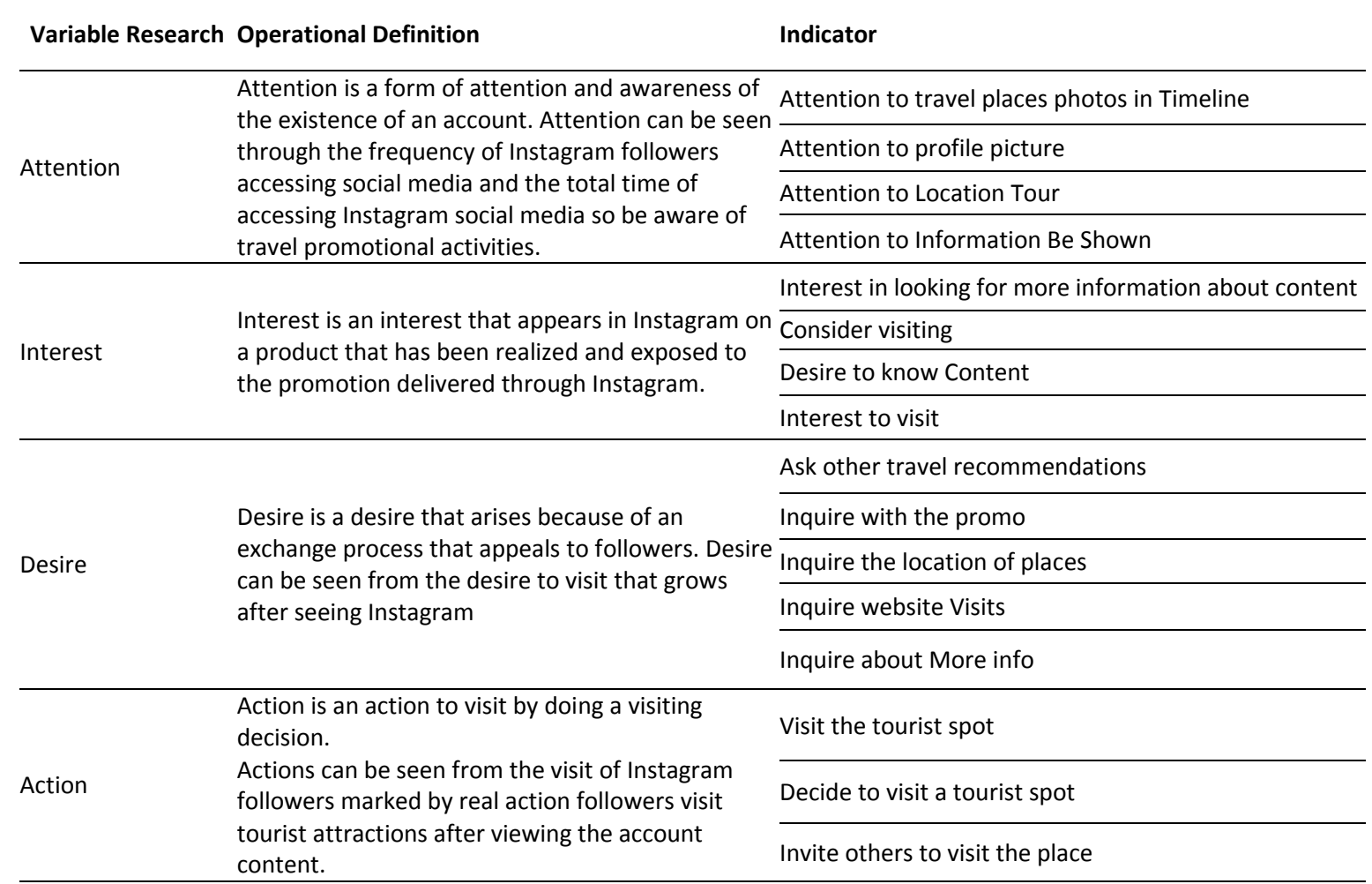




\section{RESULT AND DISCUSSION}

\section{Actual Overview of Followers}

The characteristics of Instagram followers @amazingmalang account can be seen in this study, which consists of four variables, namely: Age, Hometown, Followers Since, Frequency, and Duration (Table 2). The results showed that the average age of the 100 respondents in this study was 21 years. It appears that most respondents were in the age category of 20-24 years. It is caused by the majority of followers @amazingmalang, mostly among students or as fresh graduates. Most of the respondents came from East Java, with $82 \%$. It shows that the area around East Java indeed chose Malang as the desired tourist destination.

\section{Social Media Exposure Levels}

Exposure in this research is traced through the identification of general and specific behavior towards tourism products through the social media of Malang City. Dissertiveness is the activity of listening, seeing, and reading, or more generally giving some attention to a message delivered by using the media as an intermediary [6]. This research was conducted to measure the extent of the influence of Malang tourism social media seen from the behavior of tourism accounts@amazingmalang in Malang City.

Interest is a desire that arises in followers to find out more about tourism. It can be seen from the data above (Table 3 ) that the interest of @amazingmalang account followers is very high. It is because the content served by the @amazingmalang account is indeed interesting and makes the reader motivated to go to these tourist attractions. Here is an example post @amazingmalang that has an average number of likes 8,000 and above (Fig. 1).

Table 3. Follower Interest

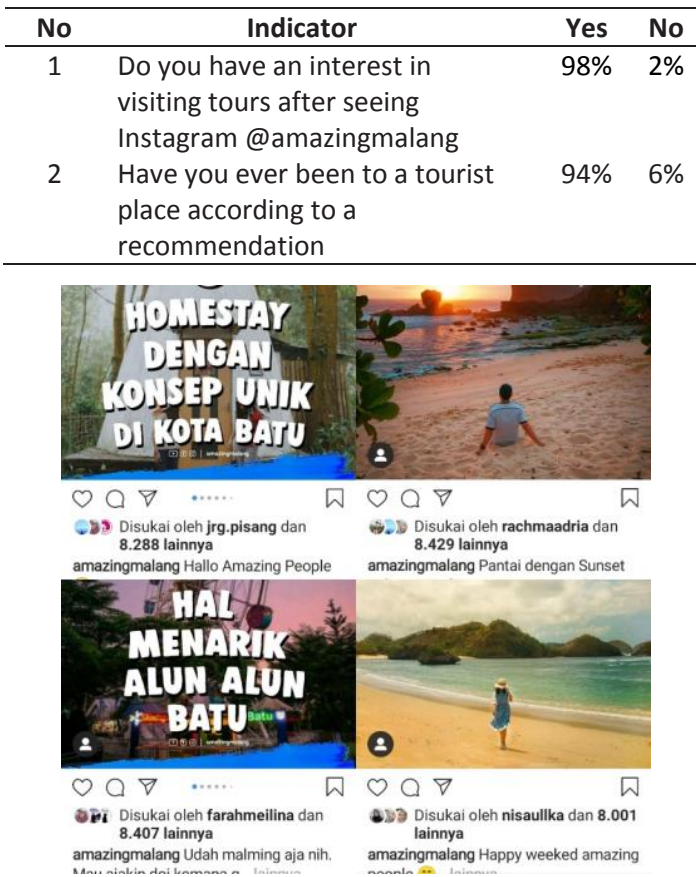

Figure 1. Content of @amazingmalang

Table 2. Number and Percentage of Active Followers

\begin{tabular}{|c|c|c|c|}
\hline No. & Characteristics of followers & Category & Percentage (\%) \\
\hline \multirow[t]{4}{*}{1} & Age & $10-18$ & 12 \\
\hline & & $19-25$ & 79 \\
\hline & & $26-35$ & 7 \\
\hline & & 36 and above & 2 \\
\hline \multirow[t]{8}{*}{2} & Hometown & Banten & 3 \\
\hline & & Jakarta & 3 \\
\hline & & Jawa Barat & 5 \\
\hline & & Jawa Tengah & 3 \\
\hline & & Jawa Timur & 82 \\
\hline & & Kalimantan Timur & 1 \\
\hline & & Nusa Tenggara Barat & 2 \\
\hline & & Riau & 1 \\
\hline \multirow[t]{4}{*}{3} & Followers Since & Less than 1 month & 36 \\
\hline & & 2 month & 7 \\
\hline & & 3 month & 6 \\
\hline & & More than 3 months & 51 \\
\hline \multirow[t]{4}{*}{4} & Frequency & 1 time a week & 53 \\
\hline & & 2 time a week & 21 \\
\hline & & 3 time a week & 7 \\
\hline & & More than 3 time a week & 19 \\
\hline \multirow[t]{4}{*}{5} & Duration & Less than $30 \mathrm{~m}$ per day & 65 \\
\hline & & 30 - 45 minutes per day & 22 \\
\hline & & 45 - 60 minutes per day & 5 \\
\hline & & More than $60 \mathrm{~m}$ per day & 8 \\
\hline
\end{tabular}


The desire that arises in the followers of @amazingmalang accounts is very high (Table 4). It is a sign that this account has indeed succeeded in influencing the desires of tourists/ followers to visit tours that have been recommended by the @amazingmalang account. In this case, many followers go on vacations by inviting friends and family, as evidenced by several followers who commented on this account by inviting friends and relatives.

Table 4. Desires of Followers

\begin{tabular}{clcc}
\hline No. & \multicolumn{1}{c}{ Indicator } & Ever & Never \\
\hline 1 & $\begin{array}{l}\text { Have you ever } \\
\text { recommended the } \\
\text { @amazingmalang } \\
\text { account to your }\end{array}$ & $91 \%$ & $9 \%$ \\
& $\begin{array}{l}\text { colleagues? } \\
\text { Have you ever looked for } \\
\text { deeper information by } \\
\text { visiting the Amazing } \\
\text { Malang website? }\end{array}$ & & \\
& & & \\
&
\end{tabular}

Comments on the @amazingmalang account show followers' interest in this account, arguably the response from followers. In a piece of information or communication, there is a reciprocal name. The @amazingmalang account shows that reciprocity from followers looks enthusiastic and fun.

The actions taken by followers are clear proof that the @amazingmalang account is on target to promote tourism in Malang through Instagram (Table 5). Some actions taken by the @amazingmalang account followers are by visiting tourist attractions; besides that @amazingmalang account also organizes promos for active followers to attract other institutional users. Here is an example of a promo given by the @amazingmalang account (Fig. 2).

Table 5. Action of Followers

\begin{tabular}{|c|c|c|c|}
\hline No. & Indicator & Ever & Never \\
\hline 1 & $\begin{array}{l}\text { Have you ever given likes to } \\
\text { the @amazingmalang } \\
\text { account? }\end{array}$ & $98 \%$ & $2 \%$ \\
\hline 2 & $\begin{array}{l}\text { Have you ever commented } \\
\text { on the @amazingmalang } \\
\text { account? }\end{array}$ & $71 \%$ & $29 \%$ \\
\hline 3 & $\begin{array}{l}\text { Have you ever followed the } \\
\text { promo on the } \\
\text { @amazingmalang account? }\end{array}$ & $68 \%$ & $32 \%$ \\
\hline 4 & $\begin{array}{l}\text { Have you ever taken the } \\
\text { quiz on the } \\
\text { @amazingmalang account? }\end{array}$ & $62 \%$ & $38 \%$ \\
\hline
\end{tabular}

Not only has that but @amazingmalang account also often held quizzes for loyal followers. Do not forget that each quiz given is always spiked with attractive prizes given by this account. One of the presents is merchandise that reads Amazing Malang. With this gift, it makes it easier for people to remember this name because it is well spread. The example of a quiz held by the @amazingmalang account showed in Figure 3.

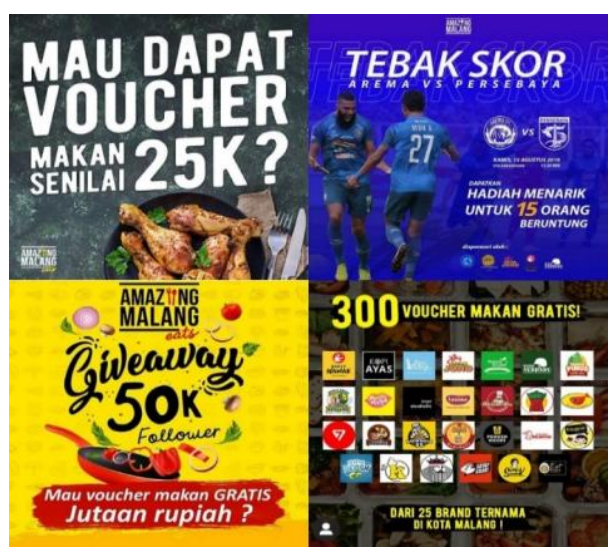

Figure 2. @amazingmalang Promo

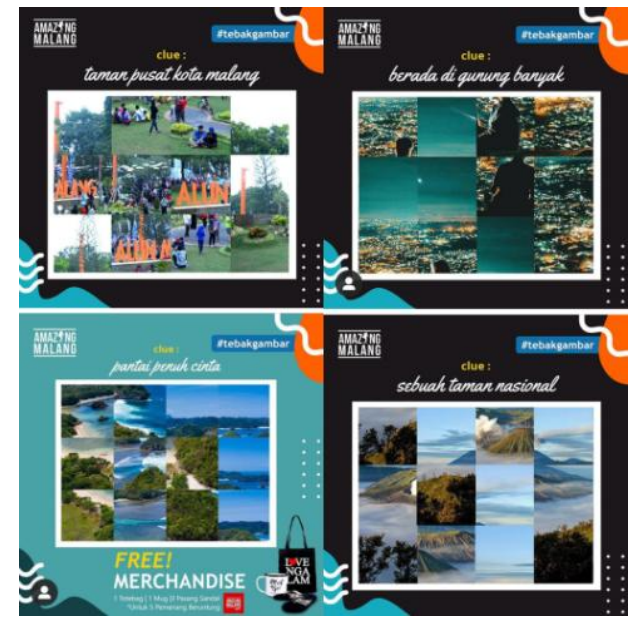

Figure 3. Instagram Quiz

Effectiveness Level of Dissemination of Media Information and Promotion

Promotion is one of the focal points of business people to introduce products and be marketed to prospective consumers. Promotion is said to be effective if the message conveyed is easily digested and understood by the public and contains correct information so that the public (consumers) can observe information with the right perspective [7]. Measurement of the effectiveness of the promotion of tourism products in Malang through social media Instagram, especially on followers @amazingmalang, is done by looking at the four stages of AIDA (Attention, Interest, Desire, and Action). A more detailed explanation can be seen in the following Table 6. 
Table 6. The Percentage of Followers of the Malang Tourism Products Instagram Account

\begin{tabular}{clc}
\hline No. & $\begin{array}{c}\text { Effectiveness of Instagram } \\
\text { Media Promotion Tourism }\end{array}$ & Percentage (\%) \\
\hline 1 & Attention & 100 \\
2 & Interest & 96 \\
3 & Desire & 84.5 \\
4 & Action & 74.75 \\
\hline
\end{tabular}

The use of the internet and other information communication technologies is leading to a new era for the global economy. Social media continues to grow and increasingly influence many social and economic aspects of the tourism and hospitality industry. Social media is fundamentally changing the way travelers and tourists' search, find, read, and trust, as well as collaboratively produce information about tourism suppliers and tourism destinations [8]. In the tourism sector, Instagram has a role as an online photo album that can be accessed by others, and users can also use it as a promotion channel [1]. This method also helps marketers to gain feedback from the customers. These benefits given by Instagram to the marketers have made Instagram as one of the strong tools in the social network marketing strategy.

Based on our observation, we analyze that Instagram becomes the best channel for promoting destination images by tourism operators. For example, the account of @amazingmalang has a result almost all respondents said the account @amazingmalang has the effectiveness of Instagram media promotion tourism by aspect attention, interest, desire, and action.

The result of this research points out that the process of promotion on Instagram is different from conventional media such as print and electronic advertising and success to promote Malang tourism. Instagram is built on interactions and inspiration from family, friends, colleagues, and acquaintances: people you know, you trust, and whose opinion you are more likely to take into account when it comes to making a travel decision [9].

The influence of Instagram is leveraged by brands as well [9], who have moved towards campaigns and content that is more human and visual. Such content is more captivating and connects to our innate desire to travel and discover. While destinations have not changed, and neither has the concept of hospitality, the modern traveler has definitely changed. The perspectives from which travelers want to explore a destination, and the tools used to share the experiences have changed considerably.

Nevertheless, Instagram has shown to be a very useful marketing tool in the new era. There still are various disadvantages when it is used as a marketing tool [1]. Firstly, the customer's information is not fully protected. Secondly, the interaction between the customer and the marketer is through a media platform. It becomes hard for the marketer to know, who their customers are, because fake identity may be created for online business. To develop an appealing and engaging brand image on Instagram, tour and activity operators should:

1. Consider the content and hashtags users might find appealing. Also, think about how to make the content memorable for users.

2. Inspire travelers by showing off the best side of the destination.

3. Collaborate with the local operator network - create an overarching vision and allow individual operators to adapt it to their services and target market.

4. Inspire travelers by creating engaging stories. Remember that travelers want to explore a destination in a deep, personal, and meaningful way.

\section{CONCLUSION}

As Instagram platforms play an important an increasingly central role in social media, it is important that users or scholars alike begin to see that these platforms are not simply as interaction or communication tools. Instagram, from a simple picture sharing and social tool, transformed into a new marketing tool in social media marketing. The results of this research showed that the effectiveness of Instagram as media promotion for tourism in Malang city in the Instagram media was in the high category. It means that promotional activities carried out were able to cause attention, interest, and feedback, and some of them carried out activities to promote travel and tourism from followers. In the future, it is necessary to activate online promotional activities that have proven to be effective in generating activities to making a travel decision (actions) from followers.

\section{REFERENCES}

[1] Vinaika, R., and D. Manik. 2017. How Instagram is changing the way marketing works? International Journal of Managemet and Business Studies 7(4), 12-16.

[2] Asosiasi Penyelenggara Jasa Internet Indonesia. 2018. Profil pengguna internet 
Indonesia. Asosiasi Penyelenggara Jasa Internet Indonesia. Jakarta.

[3] Kumparan. 2019. 8 destinasi wisata paling hits di media sosial, Jateng hingga Sulsel. Available at: kumparan.com.

[4] Sugiyono, P. D. 2015. Metode penelitian dan pengembangan. Research and Developmet D, 39-41.

[5] Gharibi, S., S. Y. S. Danesh, and K. Shahrodi. 2012. Explain the effectiveness of advertising using the AIDA Model. Interdisciplinary Journal of Contemporary Research in Business 4(2), 926-940.

[6] Trihayuningtyas, T. S. E., and Y. Adriani. 2018. Media sosial sebagai sarana informasi dan promosi (Social media as a mean of tourism information). Tourism Scientific Journal 4, 1-22.

[7] Khairani, Z., E. Soviyant, and A. Aznuriyandi. 2018. Efektivitas promosi melalui instagram pada umkm sektor makanan dan minuman di Kota Pekanbaru. Jurnal Benefita 3(2), 239. DOI: 10.22216/benefita.v3i2.2738.

[8] Zeng, B., and R. Gerritsen. 2014. What do we know about social media in tourism? A review. Tourism Management Perspectives 10, 27-36.

[9] Biagoti, M. G. 2017. How Instagram has changed the tourism and travel industry. Available at: https://www.trekksoft.com /en/blog/how-instagram-has-changed-thetourism-and-travel-industry. 